\title{
Graphene oxide synthesis for composite material preparation
}

Graphene, a material formed by carbon atoms with sp2 hybridization in a hexagonal arrangement, has differentiated characteristics in comparison to commercia materials such as high flexibility, high electrical and thermal conductivity, and strong resistance due to the organized structure of the material and can be applied in several branches of research. The best-known method for the production of graphene is the exfoliation of graphite using the methodology proposed by Hummers, in which the commercial graphite is oxidized obtaining as final product the graphene oxide that can be converted into graphene. In this study, the Hummers methodology was used in the oxidation of synthetic graphite and graphene nanoplates of $5 \mu \mathrm{m}$ and $15 \mu \mathrm{m}$. The obtained materials were characterized by FTIR, RAMAN and XRD, allowing to observe the best synthesis to be used in the production of graphene oxide. Then, composites were prepared using the graphene oxides obtained as filler. In order to obtain them, different mass quantities of graphene oxides (1\%, $3 \%$ and $5 \%$ in relation to the polypropylene polymer matrix) were used, demonstrating by the strain tensile stress tests that the composite materials have results more satisfactory than pure polypropylene.

\section{Síntese de óxido de grafeno para uso na fabricação de materiais compósitos}

\begin{abstract}
O grafeno, material formado por átomos de carbono com hibridização sp2 em un arranjo hexagonal, apresenta características diferenciadas em comparação aos materiais comerciais como alta flexibilidade, elevada condutividade elétrica e térmica, além de forte resistência devido à estrutura organizada do material podendo ser aplicado em diversos ramos da pesquisa. O método mais conhecido para a produção do grafeno consiste na exfoliação do grafite utilizando a metodologia proposta por Hummers, em que é realizada a oxidação do grafite comercial obtendo como produto final o óxido de grafeno que pode ser convertido no grafeno. Neste trabalho, a metodologia de Hummers foi empregada na oxidação do grafite sintético e de nanoplacas de grafeno de $5 \mu \mathrm{m}$ e $15 \mu \mathrm{m}$. Os materiais obtidos foram caracterizados por FTIR, RAMAN e DRX, permitindo observar qual a melhor síntese a ser empregada na produção do óxido de grafeno. Em seguida, foram preparados materiais compósitos utilizando os óxidos de grafeno obtidos como carga. Para a obtenção destes, foram utilizadas diferentes quantidades em massa de óxidos de grafeno $(1 \%, 3 \%$ e $5 \%$ em relação à matriz polimérica de polipropileno), demonstrando pelos ensaios de tensão na ruptura e de deformação, que os materiais compósitos possuem resultados mais satisfatórios que o polipropileno puro.
\end{abstract}

Palavras-chave: Polipropileno; Compósitos; Extrusão; Injeção.

Topic: Desenvolvimento, Sustentabilidade e Meio Ambiente

Reviewed anonymously in the process of blind peer
Received: 02/12/2018

Approved: 26/01/2019
Marla Corso (iD

Centro Universitário de Maringá, Brasil http://lattes.cnpq.br/5920497160956672 http://orcid.org/0000-0001-5168-5407 marlacorso@hotmail.com

Ana Carolina de Dias Albuquerque

Centro Universitário de Maringá, Brasil http://lattes.cnpq.br/8109079676275131 acdalbuquerque@hotmail.com

\section{Lídia Pereira Amaro}

Centro Universitário de Maringá, Brasil http://lattes.cnpq.br/7595758370852935 lidia amaro@hotmail.com
Lilian Keylla Berto

Centro Universitário de Maringá, Brasil http://lattes.cnpq.br/8201764678168686 lilianberto engenharia@hotmail.com

Silvia Luciana Favaro

Centro Universitário de Maringá, Brasil http://lattes.cnpq.br/6603422516062090 slfavaro@hotmail.com

Hugo Eiji Imai

Centro Universitário de Maringá, Brasil http://lattes.cnpq.br/1997348408583607 eng.hugoimai@gmail.com
Adriano Pereira Cardoso

Centro Universitário de Maringá, Brasil http://lattes.cnpq.br/2622482684854955 apcardoso96@hotmail.com

\section{Natália Ueda Yamaguchi}

Centro Universitário de Maringá, Brasil http://lattes.cnpq.br/3108348607423641 natalia.yamaguchi@unicesumar.edu.br

Luciana Cristina Soto Herek Rezende Centro Universitário de Maringá, Brasil http://lattes.cnpq.br/1158006438170059 luciana.rezende@unicesumar.edu.br FAVARO, S. L.; IMAI, H. E.; CARDOSO, A. P.; YAMAGUCHI, N. U.; REZENDE, L. C. S. H.. Graphene oxide synthesis for composite material preparation. Revista Ibero Americana de Ciências Ambientais, v.10, n.1, p.157-166, 2019. DOI: http://doi.org/10.6008/CBPC21796858.2019.001.0013 


\section{INTRODUCTION}

The branch of nanotechnology causes a great development in the technological sector due to the diversity of areas of application (BORSCHIVER et al., 2005). Among the various applications of nanotechnology, the preparation of composite materials using nanostructures provides properties that bulk materials cannot achieve due to their size and can be used as reinforcement for polymer matrices. Carbon has different structures whose properties vary with their shape and size. Some of them have nanometric forms such as graphenes, fullerenes and carbon nanotubes (ALFAYA et al., 2002).

The different types of carbon forms include graphene oxide, a solid composed of a layer of oxidized carbon atoms whose exact structure remains uncertain due to its low crystallinity, non-stoichiometric composition and thermal instability (DREYER et al., 2010). Graphene, as it does not present these surface irregularities, has excellent chemical, mechanical, optical and electronic properties attracting the attention of several research groups (GEIM, 2009).

Due to this organization of carbon atoms in graphene, its mechanical properties have very high values reaching tens of times the values presented by carbon steel. Examples of mechanical properties of graphene are high values of Young's modulus (1.5 TPa) and tensile strength (130 GPa). From this, its use in various types of composites as a reinforcing load is feasible due to the combination of these mechanical properties, the nanostructured characteristics, its low density and its high flexibility (EDA et al., 2008; LEE et al., 2008). Graphene can be obtained by different methods, such as mechanical exfoliation (NOVOSELOV, 2004), carbide sublimation (SPRINKLE et al., 2010) and chemical vapor deposition (LI et al., 2011).

One option of using graphene is through graphene oxides, these being partially oxidized graphene generated from processes involving oxidation of graphite or carbon nanotubes (HIGGINBOTHAM et al., 2010; KOSYNKIN et al., 2009). The extent of oxidation degree of graphene oxide is dependent on its preparation and the initial material (PARK et al., 2009). Graphene oxide is an intermediate structure between totally oxidized graphite, which loses its planarity, and graphene which is formed solely by carbon atoms with $\mathrm{sp}^{2}$ hybridization and hydrogen atoms in a planar structure.

Graphene is considered a revolutionary material because it is extremely strong, lightweight, flexible and excellent conductor of electricity (ZHAN et al., 2017) This material has been presenting several innovative applications (ALAM et al., 2017; HUANG et al., 2016; WU et al., 2017) and has played a significant role in the science of nanomaterials due to the diversity of its structural forms and peculiar properties

The production of composites, using nanoscale materials in their composition, presents a differential in terms of mechanical properties, thus, graphene is considered ideal to reinforce composite materials. In this case, any type of matrix can be studied, such as polymers, metals, ceramics, concrete, among others (TREACY, 1996).

A widely used polymer matrix is polypropylene (PP). The advanced applications of PP have grown significantly in the last years, because it has several crystalline modifications, which makes it a material with 
excellent tensile strength modulus, good chemical stability, high stiffness and low density, so it can be used for different industrial applications (NISAR et al., 2017; HUANGA et al., 2017)

It is a low-density resin that offers a good balance of thermal, chemical and electrical properties, accompanied by high flexural strength or fatigue strength and moderate impact strength. A peculiarity of PP is its 'folding effect', that is, one can make pieces with folds in the material, such as folding bottle lids, and eyeglass cases.

A disadvantage is its low resistance to weathering, since products obtained from PP when exposed to the sun will be stained and there will probably be loss in material properties. Polypropylenes can be easily processed in different ways, such as: injection, film extrusion, filament extrusion, thermoforming and blowing (COUTINHO et al., 2003).

In recent decades, polymeric materials have replaced other materials such as metals in various applications due to low cost, ease of processing and productivity. These materials are often modified by combining with other materials to achieve the strength required for some applications, often obtaining composite materials (CALLISTER, 2008; SAHEB et al., 1999).

The resulting properties of a composite are functions of a series of parameters such as the individual properties of the constituent materials; the surface interaction between materials; the size, shape, proportion, distribution and orientation of the reinforcement (AHMED et al., 1990). They are easily processed materials and can be shaped at low temperatures and pressures. They have lower mechanical strength than metallic and ceramic materials, so it is of interest to improve the mechanical strength of these materials by adding reinforcements for applicability in various fields, depending on their structural morphology (CALLISTER, 2008; SAHEB et al., 1999).

The thermoplastic matrix composites have advantages such as low cost and ease of processing through processes such as extrusion and injection (SORRENTINO et al, 2017). The major problem of thermoplastic-based composites is the reinforcement dispersion in the matrix, so the amount of reinforcement that the matrix supports is lower than that based on thermoset polymers in order not to hinder processability (SAHEB et al., 1999).

The materials most used as reinforcements in polymer matrix composites are synthetic fibers such as glass fibers, natural fibers such as sisal, jute, rice husk, among others; and particulate mineral reinforcements, such as talc and silica. The amount of reinforcement added to the matrix, the properties of the reinforcement material and the interaction between the reinforcement and the matrix are determinant for the properties of the composite.

Analyzing the above, this study aimed to synthetize graphene oxides using synthetic graphite and graphene nanoplates of $5 \mu \mathrm{m}$ and $15 \mu \mathrm{m}$ as precursor materials, following the Modified Hummers method, for later application in polypropylene matrix in production of composites with different properties of the starting materials. 


\section{MATERIALS AND METHODS}

\section{Manufacture of graphene oxides}

The materials used in the synthesis of graphene oxides were: synthetic graphite in chips (SigmaAldrich 99.9\%, Brasil), graphene nanoplates with an average particle diameter of 5 and $15 \mu \mathrm{m}$ (XG Sciences), P.A. potassium permanganate (Fmaia, Brasil), concentrated sulfuric acid PA (Fmaia, Brasil), hydrogen peroxide $\left(30 \% \mathrm{H}_{2} \mathrm{O}_{2}\right.$ ) (Anidrol, Brasil), P.A. hydrochloric acid (Fmaia, Brasil) and P.A. sodium chloride (Nuclear, Brasil). The syntheses were performed based on the Hummers method (HUMMERS et al., 1958).

For the first synthesis, named $\mathrm{H}$, using the modified Hummers method (KANG et al., 2016), $2.1 \mathrm{~g}$ graphite and $50 \mathrm{~mL}$ concentrated sulfuric acid were added to a beaker under magnetic stirring at $0^{\circ} \mathrm{C}$ in a thermostated bath. For two hours, at the same temperature, $6.16 \mathrm{~g}$ potassium permanganate was slowly added. After one hour, the solution was heated and held for two hours at room temperature and additional two hours at approximately $38^{\circ} \mathrm{C}$. Subsequently, the material was washed with $250 \mathrm{~mL}$ deionized water and $5 \mathrm{~mL}$ hydrogen peroxide solution $\left(30 \% \mathrm{H}_{2} \mathrm{O}_{2}\right)$ was added to reduce the remaining potassium permanganate to $\mathrm{Mn}^{2+}$ under stirring, thereafter allowing the mixture to precipitate out by $24 \mathrm{~h}$. The supernatant was removed and the resulting material was washed with $250 \mathrm{~mL} \mathrm{6M}$ hydrochloric acid, letting the graphene oxide precipitate again. Five washes were made by adding $250 \mathrm{~mL}$ deionized water to the graphene oxide, allowing to precipitate and removing the supernatant at each step. This experiment was repeated using graphene nanoplates with $5 \mu \mathrm{m}$ and $15 \mu \mathrm{m}$ as precursor materials.

For the second synthesis, called $P$, another modified methodology of the Hummers process was used (YANG et al, 2013). Initially, $1 \mathrm{~g}$ graphite powder was mixed with $60 \mathrm{~g}$ sodium chloride in a beaker. The mixture was ground in a mortar until obtaining a gray powder and the resulting material was suspended in one liter of deionized water by removing the dissociated $\mathrm{NaCl}$ in water by vacuum filtration. The material was taken to the oven at $90^{\circ} \mathrm{C}$ and, after drying, it was dissolved in $23 \mathrm{~mL}$ sulfuric acid $\left(98 \% \mathrm{H}_{2} \mathrm{SO}_{4}\right)$ under magnetic stirring for $8 \mathrm{~h}$. Under stirring, $3 \mathrm{~g}$ potassium permanganate were added in a thermostated bath with a temperature below $20^{\circ} \mathrm{C}$. The temperature was raised to $40^{\circ} \mathrm{C}$, stirring for 30 minutes and $70^{\circ} \mathrm{C}$ for 45 minutes. $3 \mathrm{~mL}$ deionized water was added, and the mixture was heated to $105^{\circ} \mathrm{C}$ for five minutes twice. An additional $40 \mathrm{~mL}$ deionized water was added at a temperature maintained at $100^{\circ} \mathrm{C}$ for fifteen minutes. The reaction was terminated by adding $140 \mathrm{~mL}$ deionized water and $10 \mathrm{~mL} 30 \% \mathrm{H}_{2} \mathrm{O}_{2}$ solution. The product was centrifuged, discarding the supernatant and washing the precipitated solid twice with hydrochloric acid (5\% $\mathrm{HCl}$ ) and then three times with deionized water. Both materials were dispersed in water with pointer ultrasound, lyophilized, stored and taken to characterization. This experiment was repeated using graphene nanoplates with $5 \mu \mathrm{m}$ and $15 \mu \mathrm{m}$ as precursor materials.

\section{Material characterization}

The characterization of the products obtained in the graphene preparation and modification processes was made using Fourier Transform Infrared Spectroscopy (FTIR) techniques using $\mathrm{KBr}$ pellets in a 
spectral range of 4000 to $500 \mathrm{~cm}^{-1}$ in a Bruker, Vertex 70V spectrophotometer; RAMAN spectrometry with $532 \mathrm{~nm}$ laser in a $2 \mathrm{~m} / \mathrm{V}$ scan using a Bruker, Senterra model, and X-ray diffraction (XRD) with radiation $\mathrm{Cu}$ $\mathrm{K} \alpha, 40 \mathrm{Kv}$ and $35 \mathrm{~mA}$, with Ni filter in an X-ray diffractometer, D8 Advance model, Bruker. The diffractograms were obtained with scanning speed of $0.5 \% / \mathrm{min}$, step of $0.02 \circ$ and angle $(2 \theta)$ between $0.5 \circ$ and $60 \circ$.

\section{Extrusion and Injection of Composites}

Different amounts of the materials obtained in the $\mathrm{H}$ and $\mathrm{P}$ syntheses were added to the polypropylene polymer matrix (PP), supplied by a recycling industry located in the city of Maringa, State of Parana3. The composite materials were prepared by extrusion using a Thermo Sientific twin-screw extruder, MiniLab II HAAKE Rheomex CTW 5, using mold temperature of $190^{\circ} \mathrm{C}$ and rotation of $60 \mathrm{RPM}$, with rectangular shape outlet profile and dimensions of $3.90 \times 1.35 \mathrm{~mm}$. The test specimens for the mechanical tests were obtained using a Thermo Sicentific injection machine, HAAKE MiniJet II, with a cannon temperature of $210^{\circ} \mathrm{C}$, mold temperature of $40^{\circ} \mathrm{C}$, injection pressure of 650 bar, injection time of $15 \mathrm{~s}$, repression pressure of 300 bar and repression pressure time of $30 \mathrm{~s}$.

\section{Characterization of composites}

The composites obtained were characterized by mechanical tensile strength tests in a universal testing machine EMIC DL 10000 with load cell of $5000 \mathrm{~N}$, test speed of $10 \mathrm{~mm} / \mathrm{min}$, according to the ASTM D 638 standard. An average of 8 tests was run for each type of composition of the different composites. The Izod impact strength tests were performed on the CEAST equipment, Resil Impactor Junior, using a $2.7 \mathrm{~J}$ pendulum. The measurements were performed following the ASTM D 256-00 standard.

\section{RESULTS AND DISCUSSION}

\section{Characterization of materials}

The analysis carried out using infrared spectroscopy (FTIR) showed that both $\mathrm{H}$ and $\mathrm{P}$ syntheses were effective in the oxidation of graphite to graphene oxide. Both syntheses were also efficient in the oxidation of graphene nanoplates of $5 \mu \mathrm{m}$ and of $15 \mu \mathrm{m}$, since the results showed typical aspects of oxygenated groups such as O-H, C-O and C=O (FENG et al., 2014), as can be seen in Fig. 1a.

FTIR spectra showed a broad band in the region of approximately $3500 \mathrm{~cm}^{-1}$ corresponding to $\left(\mathrm{V}_{\mathrm{OH}} \mathrm{C}\right.$ $\mathrm{OH}$ ) of alcohols and carboxylic acid of the surface of the material in addition to residual water. Signals in the region of approximately $2950 \mathrm{~cm}^{-1}$ represent $\left(\mathrm{V}_{\mathrm{CH}}\right)$ for $\mathrm{CH}_{2}$ covered by the broad band of $\mathrm{OH}$, while the presence of two signals observed in the region of $1630 \mathrm{~cm}^{-1}$ and $1730 \mathrm{~cm}^{-1}$ can be attributed, respectively, to $\left(\delta \mathrm{H}_{2} \mathrm{O}\right)$ and $\left(\mathrm{v}_{\mathrm{C}=\mathrm{O}}\right.$ of $\left.\mathrm{COOH}\right)$ of the groups present in the GO. There is also the presence of signals in the region of $1050 \mathrm{~cm}^{-1}$ referring to ( $\mathrm{v}_{\mathrm{c}-\mathrm{o}}$ ) of epoxy groupings in addition to the signals at $1220 \mathrm{~cm}^{-1}$ of ( $\mathrm{v}_{\mathrm{c}-\mathrm{o}-\mathrm{c}}$ ) also for epoxides. The presence of these peaks containing groups with oxygen reveals that the materials were oxidized (CHEN et al., 2010). 
The relative intensities of the oxygenated groups are different between the two syntheses, with smaller or higher intensities of these bands, especially those related to the carboxyl and epoxyl groups, showing that the three samples (graphite and graphene nanoplates) presented oxidations, generating different amounts of groups for each of the syntheses.

The samples obtained using P synthesis are richer in carboxyl groups, a result obtained for both the samples having as precursor materials the graphite or the graphene nanoplates of $5 \mu \mathrm{m}$ and $15 \mu \mathrm{m}$, shown in Fig. 1a. However, the samples synthesized by $\mathrm{H}$ presented higher amounts of epoxyl C-O groups, independently of the precursor materials are graphite or graphene nanoplates ( $5 \mu \mathrm{m}$ and $15 \mu \mathrm{m})$ as shown in Fig. 1a.

It is possible to say from the spectra that the $P$ synthesis generated a product with more effective oxidation, due to the greater broadening of the $\mathrm{OH}$ band around $3200 \mathrm{~cm}^{-1}$ and the presence of the $\mathrm{C}=\mathrm{O}$ band around $1700 \mathrm{~cm}^{-1}$ almost invisible in the spectra of the samples synthesized by $\mathrm{H}$. The Raman spectroscopy technique was used to obtain information about the structural and electronic characteristics of graphite oxide. The results indicate the bands $D$ and $G$, which indicate respectively the material defects and the vibration of $\mathrm{sp}^{2}$ carbon atoms, characteristic of all carbon composites with this hybridization (RATH et al., 2015).

Figure 1b illustrates the Raman spectra of graphene oxides. Carbon allotropes present their fingerprints in the Raman technique, with the presence of $D, G, D^{\prime}$ and $G^{\prime}\left(\right.$ or $2 D$ ) bands, around $1350 \mathrm{~cm}^{-1}$, $1580 \mathrm{~cm}^{-1}, 1620 \mathrm{~cm}^{-1}$ and $2700 \mathrm{~cm}^{-1}$, respectively. Overtones or the combination of vibrational modes depending on the condition in which the spectrum is acquired can also be observed, as in the case of the D+ $\mathrm{G}$ (at $2930 \mathrm{~cm}^{-1}$ ) and $\mathrm{G}^{\prime \prime}$ (at $3220 \mathrm{~cm}^{-1}$ ) bands (MALARD et al., 2009).

In the two syntheses, $\mathrm{H}$ and $\mathrm{P}$, the presence of bands $\mathrm{D}$ and $\mathrm{G}$ was observed around $1400 \mathrm{~cm}^{-1}$ and $1600 \mathrm{~cm}^{-1}$, respectively. Taking into account the Raman spectrum of graphite, precursor material, it is possible to notice that the structure of the material was modified due to the oxidation process, since the band D not so evident of the graphite spectrum, which indicates the organization of the structure with few defects was altered after oxidation, indicating the entry of oxygenated groups in the graphite and the defects caused by this process.

Figure $1 \mathrm{c}$ shows the diffractograms for the obtained composite materials and the precursor materials used as reinforcement (filler). It is possible to observe that the precursor materials have an XRD pattern with a peak at approximately $26^{\circ}(2 \theta)$ attributed to the turbostatic arrangement of graphene and graphite exhibiting interlayer spacing of about $3.4 \AA$. For the oxidized materials, the presence of the peak at $10^{\circ}(2 \theta)$ referring to the reflection (001) of graphene oxide with a spacing of the order of $8.4 \AA$, indicating that the processes used for the oxidation of precursor materials were effective in the preparation of the reinforcement. Since the appearance of the oxidized groups favors the interactions with the PP matrix, assisting in the mechanical properties (HUíZAR-FÉLIX et al., 2016). 

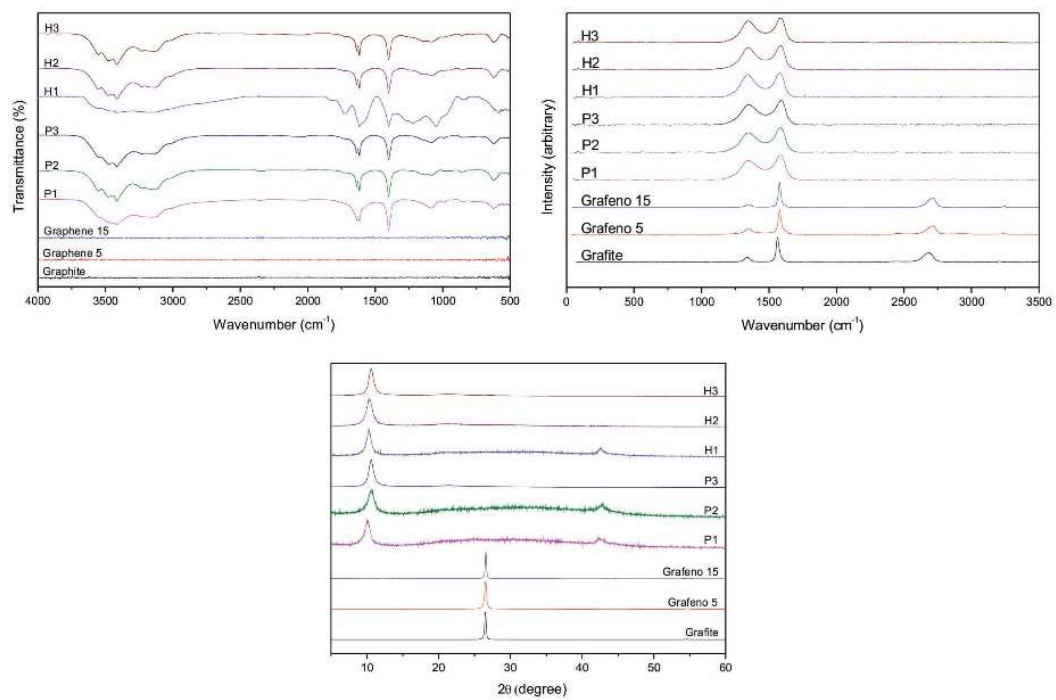

Figure 1: Results obtained for the precursor materials graphite, graphene nanoplates of $5 \mu \mathrm{m}$ and $15 \mu \mathrm{m}$ and composite materials a. Infrared spectrum (FTIR), b. Raman spectra and c. X-ray diffraction spectrum (XRD).

\section{Characterization of the test specimens}

The specimens obtained after the extrusion and injection processes were characterized by IZOD traction and impact analyses. The results for the tensile test are shown in Figs. $2 \mathrm{a}, 2 \mathrm{~b}$ and $2 \mathrm{c}$ together with the results for pure PP. Figure 2a shows the results obtained for the Modulus of Elasticity (MOE). For pure PP, the value was 92 MPa. It is possible to observe that when the materials from the syntheses were added, the values for the moduli of elasticity were greater, proportionally to the amount of material added, for $1 \%, 3 \%$ and $5 \%$, that is, when increasing the amount of material added to the polymer matrix, an increase in MOE was observed. Probably this increase was caused by the reinforcement given by the graphite blades to the polymer matrix, thus benefiting the material.
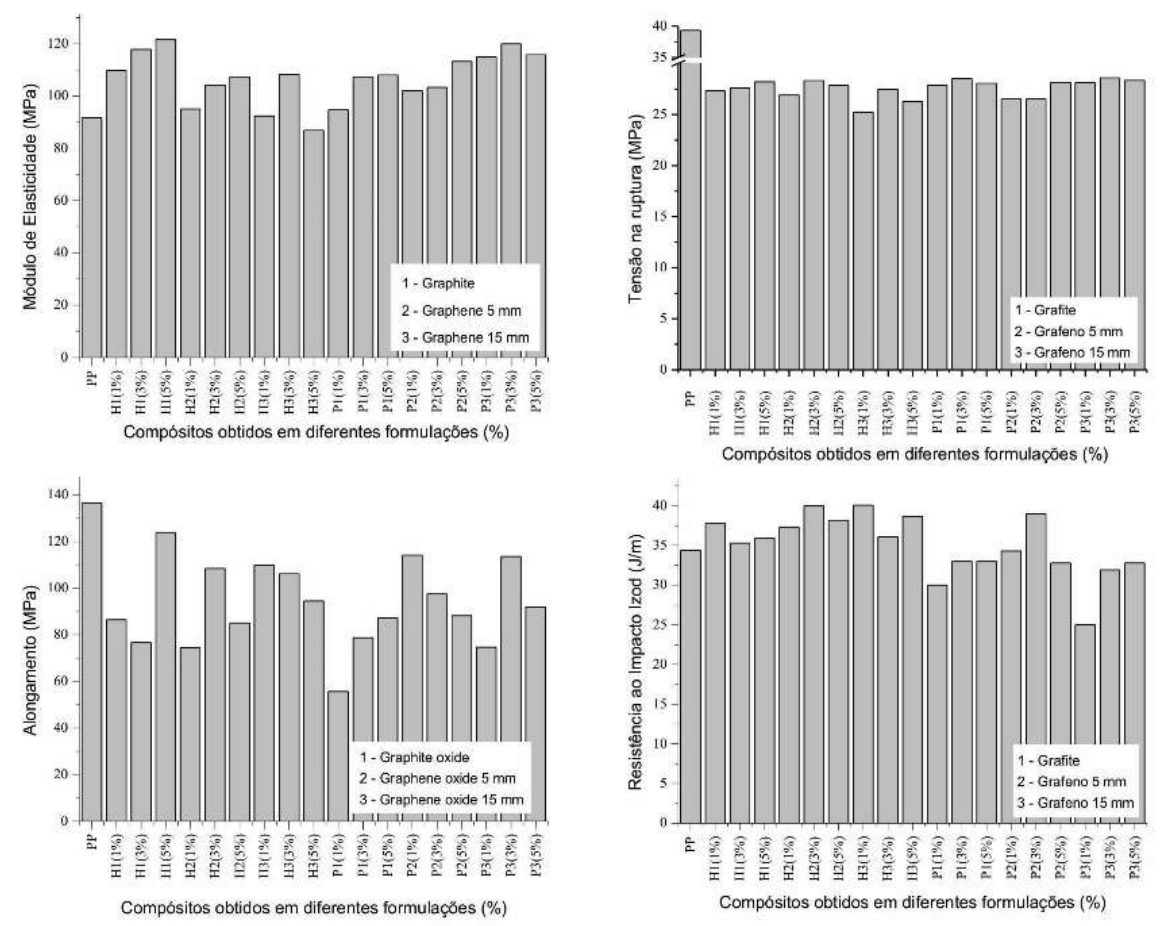

Figure 2: Composite materials obtained in the $\mathrm{H}$ and $\mathrm{P}$ syntheses and reference $\mathbf{a}$. Modulus of elasticity, $\mathbf{b}$. Tensile stress, $\mathbf{c}$. Elongation obtained and $\mathbf{d}$. Impact resistance. 
Figure $2 \mathrm{~b}$ illustrates a decrease in the values obtained for the tensile stress of the test specimens in relation to $\mathrm{PP}$, which was $39 \mathrm{MPa}$. This reduction in the values may be associated with the reduction of the mobility of molecules in the polymer matrix that are not able to dissipate the mechanical energy suffered. It may be that when reinforcement loads are added, the composites become stiffer, becoming brittle, consequently decreasing the tensile stress.

This fact can also be seen in Fig. 2c, when there is also a reduction in elongationm in which amounts of reinforcements are added to the polymer matrix. Generally, when increasing the amount of reinforcing material added, a decrease in elongation is observed. In the results obtained for the impact test, according to Fig. $2 d$, there was an increase in resistance when compared to the pure polymer for the test specimens obtained by the $\mathrm{H}$ synthesis.

For the test specimens obtained by the $\mathrm{P}$ synthesis, there was a decrease in the impact resistance when compared to the pure PP, probably from the oxidative process, which is stronger in the $\mathrm{H}$ synthesis. This fact corroborates that observed in Fig. 1a, where the material obtained using the P synthesis has a greater amount of epoxyl groups, that is, of carbonyl bonds, the interaction of this material with the polymer matrix being more difficult.

\section{CONCLUSIONS}

In this study, it was possible to synthesize and characterize graphene oxides with different degrees of oxidation for three precursor materials: synthetic graphite and graphene nanoplates with an average particle diameter of 5 and $15 \mu \mathrm{m}$, observing by infrared techniques with FTIR and Raman that the product resulting from the $P$ synthesis has undergone a more effective oxidation, having the best-defined peaks.

The composite materials presented satisfactory results for the traction test. The values obtained for the modulus of elasticity and tensile stress tests were higher than the test specimens with pure polypropylene, confirming once again an effective oxidation. Although there is a slight decrease in the impact resistance of test specimens made with graphene oxide using P synthesis, the results obtained are within the table values for polypropylene, which is $24 \mathrm{~J} \cdot \mathrm{m}^{-1}$. In this way, the $\mathrm{P}$ synthesis presented a better performance. The obtained graphene oxide is feasible to be incorporated in polypropylene polymer matrix, since it presented good mechanical properties, being economically viable.

\section{REFERENCES}

ALAM, S. N.; SHARMA, N.; KUMAR, L.. Synthesis of Graphene Oxide (GO) by Modified Hummers Method and Its Thermal Reduction to Obtain Reduced Graphene Oxide (rGO). Graphene, v.6, n.1, p.1-18, 2017. Dol:

http://doi.org/10.4236/graphene.2017.61001

ALFAYA, A. A. S.; KUBOTA, L. T.. The use of materials obtained by the sol-gel process in the construction of biosensors. New Chemistry, v.25, n.5, 2002. DOI: http://doi.org/10.1590/S0100-40422002000500020
BORSCHIVER, S.; GUIMARÃES, M. J. O. C.; SANTOS, T. N.; SILVA, F. C.; BRUM, P. R. C.. Patenting in nanotechnology: study of the sector of nanostructured polymeric materials. Polymers: science and technology, v.15, n.4, p.245-248, 2005. DOI: http://doi.org/10.1590/S0104$\underline{14282005000400007}$

CALLISTER, W. D.. Fundamentals of Materials Science and Engineering. 4 ed. São Paulo: LTC, 2014.

CHEN, W.; YAN, L.; BANGAL, P. R.. Preparation of graphene by the rapid and mild thermal reduction of graphene oxide 
induced by microwaves. Carbon, v.48, n.4, p.1146-1152, 2010. DOI: http://doi.org/10.1016/j.carbon.2009.11.037

COUTINHO, F. M. B.; MELLO, I. L.; SANTA MARIA, L. C.. Polyethylene: main types, properties and applications. Polymers, v.13, n.1, 2003. DOI:

http://doi.org/10.1590/S0104-14282003000100005

DREYER, R. D.; PARK, S.; BIELAWSKI, C. W.; RUOFF, R. S.. The chemistry of graphene oxide. Chemical Society Reviews, v.39, n.1, p.228-240, 2010. DOI:

http://doi.org/10.1039/B917103Gbn

EDA, G.; FANCHINI, G.; CHHOWALLA, M.. Large-area ultrathin films of reduced graphene oxide as a transparent and flexible electronic material. Nature Nanotechnology, v.3, n.5, p.270-274, 2008. DOI:

http://doi.org/10.1038/nnano.2008.83

FENG, H.; WU, Y.; LI, J.. Direct Exfoliation of Graphite to Graphene by a Facile Chemical Approach. Small, v.10, n.11, p.2233-2238, 2014. DOI:

http://doi.org/10.1002/smll.201303722

GEIM, A. K.. Graphene: Status and Prospects. Science, v.324, n.5934, p.1530-1534, 2009. DOI:

http://doi.org/10.1126/science.1158877

HIGGINBOTHAM, A.; KOSYNKIN, D.; SINITSKII, A.; SUN, Z.; TOUR, J. M.. Lower-Defect Graphene Oxide Nanoribbons from Multiwalled Carbon Nanotubes. ACS Nano, v.4, n.4, p.2059-2069, 2010. DOI: http://doi.org/10.1021/nn100118m

HUANG, H.; MA, L.; TIWARY, C. S.; JIANG, Q.; YIN, K.; ZHOU, W.; AJAYAN, P. M.. Worm-Shape Pt Nanocrystals Grown on Nitrogen-Doped Low-Defect Graphene Sheets: Highly Efficient Electrocatalysts for Methanol Oxidation Reaction. Small, v.13, n.10, 2016. Dol:

http://doi.org/10.1002/smll.201603013

HUANGA, J.; XU, C.; WU, D.; LY, Q.. Transcrystallization of polypropylene in the presence of polyester/cellulose nanocrystal composite fibers. Carbohydrate Polymers, v.15, n.2, p.297-301, 2017. DOI:

http://doi.org/10.1016/j.carbpol.2017.03.046

HUÍZAR-FÉLIX, A. M.; CRUZ-SILVA, R.; BARANDIARÁN, J. M.; GARCÍA-GUTIÉRREZ, D. I.; ORUE, I.; MERIDA, D.; SEPÚLVEDAGUZMÁN, S.. Magnetic properties of thermally reduced graphene oxide decorated with PtNi nanoparticles. Journal of Alloys and Compounds, v.678, p.541-548, 2016. DOI: http://doi.org/10.1016/j.jallcom.2016.03.261

HUMMERS, W. S.; OFFEMAN, R. E.. Preparation of Graphitic Oxide. Journal of the American Chemical Society, v.80, n.6, p.1339-1339, 1958. DOI:

http://doi.org/10.1021/ja01539a017

KANG, J. H.; KIM, T.; CHOI, J.; PARK, J.; KIM, Y. S.; CHANG, M. S.; JUNG, H.; PARK, K. T.; YANG, S. J.; PARK, C. R.. Hidden Second Oxidation Step of Hummers Method. Chemistry of

Materials, v.28, n.3, p.756-764, 2016. DOI:

http://doi.org/10.1021/acs.chemmater.5b03700

KOSYNKIN, D.; HIGGINBOTHAM, A.; SINITSKII, A.; LOMEDA, J.; DIMIEV, A.; PRICE, K.; TOUR, J.. Longitudinal unzipping of carbon nanotubes to form graphene nanoribbons. Nature, v.458, n.7240, p.872-876, 2009. DOI:

http://doi.org/10.1038/nature07872

LEE, C.; WEI, X.; KYSAR, J. W.; HONE, J.. Measurement of the Elastic Properties and Intrinsic Strength of Monolayer Graphene. Science, n.321, n.5887, p.385-388, 2008. DOI: http://doi.org/10.1126/science.1157996

LI, X.; MAGNUSON, C. W.; VENUGOPAL, A.; TROMP, R. M.; HANNON, J. B.; VOGEL, E. M.; COLOMBO, L.; RUOFF, R. S.. Large-Area Graphene Single Crystals Grown by Low-Pressure Chemical Vapor Deposition of Methane on Copper. Journal of the American Chemical Society, v.133, n.9, p.2816-2819, 2011. DOI: http://doi.org/10.1021/ja109793s

MALARD, L. M.; PIMENTA, M. A.; DRESSELHAUS, G.; DRESSELHAUS, M. S.. Raman spectroscopy in graphene. Physics Reports, v.473, n.5-6, p.51-87, 2009. DOI: http://doi.org/10.1016/j.physrep.2009.02.003

NISAR, M.; BERGMANN, C. P.; GESHEV, J.; QUIJADA, R.; GALLAND, G. B.. Synthesis and characterization of polypropylene/iron encapsulated carbon nanotube composites with high magnetic response at room temperature. Polymer, v.118, n.2, p.68-74, 2017. DOI: http://doi.org/10.1016/j.polymer.2017.04.067

NOVOSELOV, K. S.; GEIM, A. K.; MOROZOV, S. V.; JIANG, D.; ZHANG, Y.; DUBONOS, S. V.; GRIGORIEVA, I. V.; FIRSOV, A.. Electric Field Effect in Atomically Thin Carbon Films. Science, v.306, n.5696, p.666-669, 2004. DOI: http://doi.org/10.1126/science.1102896

PARK, S.; RUOFF, R. S.. Chemical methods for the production of graphenes. Nature Nanotechnology, v.4, n.4, p.217-224, 2009. DOI: http://doi.org/10.1038/nnano.2009.58

RATH, T.; KUNDU, P.. Reduced graphene oxide paper based nanocomposite materials for flexible supercapacitors. RSC Adv., v.5, p.26666-26674, 2015. DOI: http://doi.org/10.1039/C5RA00563A

SAHEB, D. N.; JOG, J. P.. Natural Fiber Polymer Composites: A Review. Advances in Polymer Technology. Wiley, v.18, n.4, p.351-363, 1999. DOI:

http://doi.org/10.1002/\%28SICl\%2910982329\%28199924\%2918\%3A4<351\%3A\%3AAIDADV6>3.0.CO\%3B2-X

SORRENTINO, L.; VASCONCELLOS, D. S.; D'AURIA, M.; SARASINI, F.; TIRILLO, J.. Effect of temperature on static and low velocity impact properties of thermoplastic composites. Composites Part B: Engineering, v.113, p.100-110, 2017. DOI: http://doi.org/10.1016/j.compositesb.2017.01.010

SPRINKLE, M.; HICKS, J.; TEJEDA, A.; TALEB-IBRAHIMI, A.; FEVRE, P.; BERTRAN, F.; TINKLEY, H.; CLARK, M.; SOUKIASSIAN, P.; MARTINOTTI, D.; HASS, J.; CONRAD, E. H.. Multilayer epitaxial graphene grown on the SiC surface; structure and electronic properties. Journal of Physics D., v.43, n.37, 2010. DOI: http://doi.org/10.1088/0022$3727 / 43 / 37 / 374006$

TREACY, M. M. J.; EBBESEN, T. W.; GIBSON, J. M..

Exceptionally high Young's modulus observed for individual 
carbon nanotubes. Nature, v.381, n.6584, p.678-680, 1996. DOI: $\underline{\text { http://doi.org/10.1038/381678a0 }}$

WU, L.; HAO, L.; PANG, B.; WANG, G.; ZHANG, Y.; LI, X.. $\mathrm{MnO2}$ nanoflowers and polyaniline nanoribbons grown on hybrid graphene/Ni 3D scaffolds by in situ electrochemical techniques for high-performance asymmetric supercapacitors. J. Mater. Chem. A., v.5, n.9, p.4629- 4637, 2017. DOI: http://doi.org/10.1039/C6TA10757E
YANG, K.; FENG, L.; HONG, H.; CAI, W.; LIU, Z.. Preparation and functionalization of graphene nanocomposites for biomedical applications. Nature Protocols, v.8, n.12, p.23922403, 2013. DOI: http://doi.org/10.1038/nprot.2013

ZHAN, Y.; MENG, Y.; LI, Y.. Electric heating behavior of flexible graphene/natural rubber conductor with self-healing conductive network. Materials Letters, v.192, n.4, p.115118, 2017. DOI: http://doi.org/10.1016/j.matlet.2016.12.045

A CBPC - Companhia Brasileira de Produção Científica (CNPJ: 11.221.422/0001-03) detém os direitos materiais desta publicação. Os direitos referem-se à publicação do trabalho em qualquer parte do mundo, incluindo os direitos às renovações, expansões e disseminações da contribuição, bem como outros direitos subsidiários. Todos os trabalhos publicados eletronicamente poderão posteriormente ser publicados em coletâneas impressas sob coordenação da Sustenere Publishing, da Companhia Brasileira de Produção Científica e seus parceiros autorizados. Os (as) autores (as) preservam os direitos autorais, mas não têm permissão para a publicação da contribuição em outro meio, impresso ou digital, em português ou em tradução. 